\title{
Profile of Haematology and Biochemistry of Aceh Polled and Horned Cow
}

\author{
Yudha Fahrimal ${ }^{1 *}$, Nuzul Asmilia ${ }^{2}$, Siti Aisyah ${ }^{3}$, Fitri R. Yanti ${ }^{3}$, Erina Erina $^{4}$, Faridha Athailah ${ }^{1}$, and Al Azhar ${ }^{5}$ \\ ${ }^{1}$ Parasitology Laboratory of the Faculty of Veterinary Medicine, Syiah Kuala University, Indonesia \\ ${ }^{2}$ Clinical Laboratory of the Faculty of Veterinary Medicine, Syiah Kuala University, Indonesia \\ ${ }^{3}$ Veterinary Study Program, Faculty of Veterinary Medicine, Syiah Kuala University, Indonesia \\ ${ }^{4}$ Microbiology Laboratory, Faculty of Veterinary Medicine, Syiah Kuala University, Indonesia \\ ${ }^{5}$ Biochemistry Laboratory of the Faculty of Veterinary Medicine, Syiah Kuala University, Indonesia
}

\begin{abstract}
As one of the Local wisdom in Aceh, farmer prefers raising polled cow than horned cow for breeding purposes. They believe pole cow is more resilient in harsh conditions and reproductively better than the horned cow. The aim of this study was to evaluate blood profile and blood biochemistry of the aceh polled and horned cow. The blood profile examined includes erythrocyte value, erythrocyte indices MCV (Mean Corpuscular Volume), MCH (Mean Corpuscular Hemoglobin), MCHC (Mean Corpuscular Hemoglobin Concentration), thrombocyte, leukocyte, hematocrit, and hemoglobin, while blood biochemistry includes protein total, glucose, cholesterol, and ureum. Blood was collected from 15 aceh horned and 15 pole cow raised at Research Institute of Improved Livestock and Livestock Fodder (BPTU HPT) Indrapuri, Aceh Besar regency, province of Aceh, Indonesia. The cows were clinically healthy and aged 1,5-2,5 years old. Blood profile was measured using a hematology analyzer and blood biochemistry was measured using a Yuesen Med and Spectrophotometer. Based on the statistic analysis, blood profile and blood biochemistry of the aceh horned and polled cow on all parameters showed no significant difference $(\mathrm{P}>0,05)$. It is therefore concluded that there are no different value of blood profile and blood biochemistry between polled and horned cow.
\end{abstract}

Keywords: blood profile, blood Biochemistry, aceh pole, horned cow.

\section{Introduction}

Aceh cattle (Bos indicus) is one of four native Indonesian cattle (Aceh, Pesisir, Madura, and Bali) [1]. Aceh cattle is designated as one of the local cattle families in Indonesia through the Decree of the Minister of Agriculture of the Republic of Indonesia Number: 2907/Kpts/OT.140/6/2011, which has an original geographical distribution in Aceh Province and has been cultivated for generations. Aceh cows are a wealth of Indonesian livestock genetic resources that need to be protected and preserved [2]. Aceh cows are generally horned, but a small portion of them are polled cows (7\%) [1]. Furthermore, aceh cows at Livestock Breeding Center and Forage Feed (BPTU HPT) Indrapuri, Aceh was polled cows [3]. One of local wisdom in Aceh province in livestock raiser, breeders prefer to raise polled cow than horned one for breeding purpose. They said that aceh polled cows have advantages over horned ones including, more adaptive and resilient in the harsh environment, having heavier bodyweight, faster puberty, and shorter calving intervals than horned Acehnese cows with the same age range.

Blood is one of the physiological parameters that reflects the physical condition of livestock. The use of clinical biochemical parameters in veterinary medicine is very often done to determine the health status of animals $[4,5]$. Some biochemical tests of blood and other body fluids in livestock can be used to explain the mechanism of the occurrence of irregularities, provide an overview of health conditions, metabolic status and help establish the diagnosis, so that appropriate treatment can be given [6]).

This study describes haematological and biochemical profiles of aceh horned and polled cows. Haematology profiles describe erythrocyte values, erythrocyte index MCV (Mean Corpuscular Volume), $\mathrm{MCH}$ (Mean Corpuscular Haemoglobin), MCHC (Mean Corpuscular Haemoglobin Concentration), platelets, leukocytes, haematocrit, and haemoglobin and biochemical profiles including total protein, glucose, cholesterol, and urea in aceh horned and polled cows.

\section{Materials and Methods}

\subsection{Blood sampling}

Blood samples were taken at the Livestock Breeding Center and Livestock Feed Forage (BPTU-HPT) Indrapuri, Aceh Besar, randomly 15 horned female aceh cows and 15 polled aceh cows in BPTU-HPT Indrapuri. Blood was drawn from 15 horned and 15 polled cow through the jugular vein using $3 \mathrm{ml}$ vacutainer tubes. The

* Corresponding author: yudhafahrimal@unsyiah.ac.id 
blood was temporarily stored in an icebox and immediately taken to the laboratory for examination.

\subsection{Hematological and Biochemical Examination of Blood}

Collected blood samples were examined using Mindray brand hematology analyzer to obtain the number of erythrocytes, leukocytes, platelets, erythrocyte index (MCV, MCH, MCHC), hematocrit, and hemoglobin and for total blood protein levels, blood glucose levels, blood cholesterol levels and blood urea levels using a Yuesen Med brand spectrophotometer.

\section{Results and Discussion}

The number of erythrocytes, erythrocyte indexes, leukocytes, haematocrit, and haemoglobin of female horned and polled cows can be seen in Table 1 .

Table 1. Average ( \pm SD) the results of the calculation of the blood profile of aceh female horned and polled cows.

\begin{tabular}{|c|c|c|c|}
\hline Blood profile & $\begin{array}{l}\text { Horned } \\
\text { aceh } \\
\text { cows. }\end{array}$ & & Polled aceh cows \\
\hline Erythrocytes $\left(10^{6} / \mu 1\right)$ & $\begin{array}{l}8.61 \\
0.91\end{array}$ & \pm & $8.86 \pm 0.49$ \\
\hline MCV (fl & $\begin{array}{l}47.85 \\
5.31\end{array}$ & \pm & $45.90 \pm 4.28$ \\
\hline $\mathrm{MCH}(\mathrm{pg})$ & $\begin{array}{l}14.57 \\
1.11\end{array}$ & \pm & $14.03 \pm 1.23$ \\
\hline MCHC (g/dl) & $\begin{array}{l}30.42 \\
1.53\end{array}$ & \pm & $30.70 \pm 0.81$ \\
\hline Platelets $\left(10^{3} / \mu\right)$ & $\begin{array}{l}2.67 \\
0.44\end{array}$ & \pm & $2.87 \pm 0.33$ \\
\hline Leukocytes $\left(10^{3} / \mu \mathrm{l}\right)$ & $\begin{array}{l}9.64 \\
1.80\end{array}$ & \pm & $9.06 \pm 2.75$ \\
\hline Hematocrit (\%) & $\begin{array}{l}41.43 \\
6.34\end{array}$ & \pm & $40.64 \pm 4.61$ \\
\hline Hemoglobin (g/dl) & $\begin{array}{l}12.57 \\
1.58\end{array}$ & \pm & $12.49 \pm 1.39$ \\
\hline
\end{tabular}

\subsection{Erythrocyte Value}

The results of statistical analysis using the student t-test showed that the erythrocyte value of horned and polled aceh cows was not significantly different $(\mathrm{P}>0.05)$. The average number of erythrocytes of horned aceh cows was $8.61 \pm 0.91\left(10^{6} / \mu 1\right)$ and polled cows $8.8 \pm 0.49\left(10^{6} / \mu 1\right)$. Although it is not significantly different, there is a tendency of erythrocytes value in polled cows is higher than horned cows, showing a better health condition.

The number of erythrocytes is influenced by nutrients in the feed, age, sex, pregnancy, lactation, climate, oestrous phase and height of location can also affect the number of erythrocytes [7]. The external factors found in the Indrapuri BPTU-HPT namely feed, climate and altitude are the same so that in this case there is no noticeable difference between the erythrocytes of the horned and polled cows. The superiority of aceh polled cow over horned cow claimed by the farmer may not be significant in a better condition where feed and other conditions are adequate such as in the BPTU-HMT institute.

The average erythrocytes of horned and polled cows of aceh cow in this study were higher but not much different than the average of erythrocytes of aceh cows and bulls studied by [8]. They found that the number of erythrocytes for aceh cows and bulls were $7.34\left(10^{6} / \mathrm{mm}^{3}\right)$ and $7.75\left(10^{6} / \mathrm{mm}^{3}\right)$ consecutively. This is caused by feed, breeding systems, different environmental conditions. Adam et al. (2015) stated that nutritional factors influence the number of erythrocytes in cattle. Adequate nutrition in the feed will produce a normal amount of erythrocytes and lies in the normal high range of cow's blood. In BPTUHPT, the cows are provided with good quality and quantity feed so that the average erythrocytes of horned and polled Acehnese cattle are higher than free grazing cows as shown by [8].

Examination of the erythrocyte index is used to diagnose anemia and determine anemia based on morphology. Based on the statistical analysis of the student t-test, it was shown that the MCV values of horned and polled aceh cows were not significantly different $(\mathrm{P}>$ $0.05)$. The average MCV value of horned aceh cows was $47.85 \pm 5.31(\mathrm{fl})$ and the polled aceh cows $45.90 \pm 4.28$ (fl). The normal MCV value in beef cattle is 36-50 (fl) [9], in this case, the MCV values of horned and polled cows are in the normal range.

$\mathrm{MCH}$ value also did not show any significant difference $(\mathrm{P}>0.05)$. The average $\mathrm{MCH}$ values of horned and polled cows were $14.57 \pm 1.11(\mathrm{pg})$ and $14.03 \pm 1.23$ (pg) respectively. Likewise, the value of MCHC did not show any significant difference $(\mathrm{P}>0.05)$ with the average value of MCHC in horned cows of Aceh $30.42 \pm$ $1.53(\mathrm{~g} / \mathrm{dl})$ and cows of Aceh cows in $30.70 \pm 0.81(\mathrm{~g} / \mathrm{dl})$. The MCH values in horned and pole cows are within the normal range compared to [9] reports where $\mathrm{MCH}$ values in beef cattle normally range from 14-19 (pg) but MCHC values are below the normal range of $38-43(\mathrm{~g} / \mathrm{dl})$.

Statistical analysis showed that the values of MCV, $\mathrm{MCH}$, and $\mathrm{MCHC}$ did not show any significant difference between horned and polled cows. This finding in accordance with the results of physical health check that the horned and polled cows are in healthy condition. Although the MCV and MCH values of horned aceh and polled cows were not significantly different, it was seen that the MCV and MCH values of horned aceh cows tended to be higher than that those of polled aceh cows. However, the MCHC value of polled cows tends to be higher than the MCHC value of horned cows

\subsection{Platelet Count}

The number of platelets of horned aceh and polled cows did not show any significant difference based on the statistical analysis of the student T-test $(\mathrm{P}>0.05)$, the average value of platelet counts in each cow was $2.67 \pm 0.44\left(10^{3} / \mu \mathrm{l}\right)$ and $2.87 \pm 0.33\left(10^{3} / \mu \mathrm{l}\right)$. Although not significantly different, the platelet counts of polled aceh cows tend to be higher than those of horned aceh cows. As with other blood profile values, platelet counts did not show any significant difference between horned and 
polled aceh cows caused by external factors in the Indrapuri BPTU-HPT.

\subsection{Leucocyte Value}

The statistical results of the student t-test on the number of leukocytes did not show any significant difference between horned and polled cows. The average number of leukocytes of horned aceh cow was $9.64 \pm 1.80\left(10^{3} / \mu \mathrm{l}\right)$ and the polled aceh cows was $9.06 \pm 2.75\left(10^{3 / \mu l}\right)$. Nevertheless, it is seen that the leukocyte value of horned aceh cows tends to be higher than that of polled cows. The number of white blood cells in animals varies depending on the type of animal, breed, age, sex, and condition of the animal [10].

\subsection{Haematocrit and Haemoglobin levels}

The average haematocrit levels of horned and polled aceh cow were $41.43 \pm 6.34(\%)$ and $40.64 \pm 4.61(\%)$ respectively and there was no significant difference (P>0.05). Similarly, the average haemoglobin level also did not show any significant difference $(\mathrm{P}>0.05)$ ie 12.57 $\pm 1.58(\mathrm{~g} / \mathrm{dl})$ and $12.49 \pm 1.38(\mathrm{~g} / \mathrm{dl})$. However, it was seen that the haematocrit and haemoglobin levels of horned cows tended to be higher than that of aceh cows. Differences in blood haematocrit levels are due to differences in age, production levels, breeding systems and seasons. While some factors that influence the value of haemoglobin include the age of the animal, species, environment, season, feed, presence or absence of erythrocyte damage, the time of sampling, the type of anticoagulant used and the method used $[11,12]$.

The average haematocrit levels of horned and polled cows in this study were higher but not much different than the average haematocrit levels of aceh cows examined by [8] which were $32.8 \%$ and $32.6 \%$, respectively. The cows examined by Adam et al. (2015) were free grazing cows that might not get adequate quantity and quality of feed. Moreover, the cows were probably not dewormed regularly. Levels of total blood protein, glucose, cholesterol, and urea in horned and polled cows are presented in Table 2.

Table 2 Blood biochemical results in horned and pole Aceh cattle

\begin{tabular}{lll}
\hline $\begin{array}{l}\text { Biochemical profile } \\
\text { of blood }\end{array}$ & $\begin{array}{l}\text { Horned } \\
\text { cows }\end{array}$ & Polled cows \\
\hline Total protein $(\mathrm{g} / \mathrm{dl})$ & $\begin{array}{l}7.54 \pm \\
0.88^{\mathrm{a}}\end{array}$ & $11.73 \pm 18.50^{\mathrm{a}}$ \\
& $19.15 \pm$ & $22.33 \pm 7.22^{\mathrm{a}}$ \\
Glucose $(\mathrm{mg} / \mathrm{dl})$ & $3.74^{\mathrm{a}}$ & \\
& $78.76 \pm$ & $64.87 \pm 25.46^{\mathrm{a}}$ \\
$(\mathrm{mg} / \mathrm{dl})$ & $27.50^{\mathrm{a}}$ & \\
& $0.61 \pm$ & $0.82 \pm 0.85^{\mathrm{a}}$ \\
Urea $(\mathrm{mg} / \mathrm{dl})$ & $0.90^{\mathrm{a}}$ & \\
\hline
\end{tabular}

a Same superscript in the same line shows no significant difference $(\mathrm{P}>0.05)$

\subsection{Total Protein Levels}

Total protein content in horned cows and polled cows were $(\mathrm{P}>0.05)$ ie $7.54 \pm 0.88 \mathrm{~g} / \mathrm{dl}$ and $11.73 \pm 18.50$ $\mathrm{g} / \mathrm{dl}$. The values are not statistically different $(\mathrm{P}>0.05)$, however, there is a tendency that the total protein concentration in aceh polled cows is higher than that of horned aceh cows. The standard reference for total protein in beef cattle is $5.7-8.1 \mathrm{~g} / \mathrm{dl}$ [13]. The total protein content in horned aceh cows in this study is within the normal range, while the total protein level in polled cows is higher than the standard reference in beef cattle. Other studies indicate that the serum protein content of beef cattle and dairy cattle are different. Another study reported that the total serum protein concentration of dairy cow blood is $7.56 \pm 0.50 \mathrm{~g} / \mathrm{dl}[14]$. This is consistent with the results of research conducted by [6] in Simmental bulls, where the average total protein concentration in Simmental bulls was $19.94 \%$ higher than the standard reference in dairy cows.

\subsection{Glucose level}

The glucose level in horned Aceh cattle and polled cows did not show any significant difference $(\mathrm{P}>0.05)$ ie 19.15 \pm 3.74 respectively $\mathrm{mg} / \mathrm{dl}$ and $22.33 \pm 7.22 \mathrm{mg} / \mathrm{dl}$. Although not significantly different, there is a tendency for glucose concentration in the polled cows is higher than those of the horned cows. The average blood glucose levels of horned cows and polled cows are lower than the study in bali cattle [15]. The glucose level of bali cattle is $68.96-72.81 \mathrm{mg} / \mathrm{dl}$ and $65.85-68.91 \mathrm{mg} / \mathrm{dl}$, and 68.96 to 72.00 in young and adult bali cattle respectively. According to [16], the normal range of blood glucose levels in normal cattle varies between $43-100 \mathrm{mg} / \mathrm{dl}$, whereas according to [17], blood glucose levels in ruminants range from $70-120 \mathrm{mg} / \mathrm{dl}$. Normally this blood glucose level is not only due to the energy factor supplied by the food consumed, but also due to the control mechanism by the insulin and glucagon hormones that regulate the balance of blood glucose content in livestock [18].

According to [7], the result of carbohydrate digestion in ruminants in reticulum rumen is volatile fatty acids (VFA/volatile fatty acids), especially acetic acid, propionate, and butyrate which will be absorbed before reaching the intestine. Volatile fatty acids will then be absorbed into the bloodstream into the liver, and in the liver, VFA will be converted into glucose, as well as other results needed by the body [19]. Glucose in ruminants aside from being an energy source after VFA is also important in the maintenance of body cells, especially blood and muscles [20]. While [21] states that glucose in the blood is released continuously to nourish various body tissues

\subsection{Total cholesterol}

Total cholesterol is an arrangement of many substances, including triglycerides, low-density lipoprotein (LDL) cholesterol, and high-density lipoprotein (HDL). The cholesterol contained in LDL is captured by a special 
receptor in peripheral tissue. Excess cholesterol in peripheral tissues is transported by HDL to the liver and then excreted through the bile ducts as bile acids [22]. According to [23], cholesterol is also an important element in the plasma membrane, ie cholesterol is the precursor for all other steroids synthesized in the body such as the adrenal cortex hormones and sex hormones, vitamin $\mathrm{D}$, and bile acids.

Cholesterol levels in horned cows and polled cows were $78.76 \pm 27.50 \mathrm{mg} / \mathrm{dl}$ and $64.87 \pm 25.46 \mathrm{mg} / \mathrm{dl}$ respectively. Although they are not significantly different ( $\mathrm{P}>0.05)$, there is a tendency that the concentration of cholesterol in polled cows is lower than that of horned cows. The average blood cholesterol levels of horned and polled aceh cow in this study are lower than the study done by [24] that Ongole crossbreed cattle (PO) and Simmental cattle PO (simpo) which were $113.66 \pm 1,11$ $\mathrm{mg} / \mathrm{dl}$ and $107.04 \pm 39.88 \mathrm{mg} / \mathrm{dl}$ respectively. Low levels of aceh cow cholesterol in the two groups studied could also be caused by low fat in the feed ration and affect the reproductive process [25] or these levels are indeed normal levels of aceh cow cholesterol because there has been no previous research.

\subsection{Urea levels}

Urea levels in horned and polled cows did not show any significant difference $(\mathrm{P}>0.05)$ ie $0.61 \pm 0.90 \mathrm{mg} / \mathrm{dl}$, and $0.82 \pm 0.85 \mathrm{mg} / \mathrm{dl}$ respectively. Although not significantly different, there is a tendency that the concentration of urea in aceh polled cows is higher than that of horned aceh cows. Blood urea results from this study are also below the range of urea blood in Bali according to [15] blood urea levels in male and female bali cows are 1.78-2.03 $\mathrm{mg} / \mathrm{dl}$ and 1.93-2.07 $\mathrm{mg} / \mathrm{dl}$, respectively, in young and adult cows are $75-1.91 \mathrm{mg} / \mathrm{dl}$ and $1.98-2.15 \mathrm{mg} / \mathrm{dl}$ respectively.

Measurement of blood urea concentration is useful for determining high concentrations of ammonia $\left(\mathrm{NH}_{3}\right)$ in the rumen and low energy consumption by livestock, while according to [26] blood urea concentrations are related to fertility and available energy. The efficiency of utilizing $\mathrm{NH}_{3}$ for protein synthesis in the rumen depends on energy availability. The concentration of urea nitrogen in the blood is influenced by various interrelated parameters namely protein and carbohydrate intake, rumen degradation ability, amino acid composition in diet, liver function, kidney function, and damage to muscle tissue [27].

This research is still in its early stages and there are many more factors that need to be investigated to prove that polled aceh cow is of Acehnese cattle, when viewed from quantitative traits as the author's survey of body weight, reproductive traits such as puberty and calving intervals. Opinions circulating in the community stating that polled cows better than horned cows are based on years of observation and on the natural environmental conditions as they are and almost without intervention in livestock management and the animals feed only what nature provides and without health care. Whereas, in BPTU-HPT, the animals are fed with good quality feed adequately, so that no noticeable difference is seen in the blood profile and blood biochemistry values of the horned and polled cows. However, a study was done by Iswandi ((2018, unpublished data) to see gastrointestinal nematodes infestation in free-grazing cows shows that polled cows have significantly fewer eggs count per gram compared to that of horned cows $(\mathrm{P}<0.05)$

\section{Conclusion}

There is no significant difference between the values of erythrocytes, erythrocyte indices, platelets, leukocytes, haematocrit, and haemorrhages of horned and polled cows, and the biochemical profile of the blood of horned and polled cows, but there is a tendency of total protein concentration, glucose and blood urea in horned cow higher than that of polled cows, whereas the concentration of cholesterol was higher in horned cows compared to polled cows.

\section{Acknowledgments}

We would like to thank the head of BPTU-HMT Indrapuri for granting permission to collect blood samples and field staff for their assistance in blood collection.

\section{References}

1. Abdullah MAN: Correlation of aceh cattle relationship using displacement-loop region. J. Agripet. 2008; 8(2): 9-14.

2. Putra WPB, Sumadi T, Hartaik, et al Selection of aceh cattle based on selection index and breeding value. $J$. Peternakan Sriwijaya. 2015; 4(1):1-10.

3. Mukhtar, Jamaliah, Saumar H: Phenotype Diversity of Female Aceh Cattle in BPTU-HPT Indrapuri. Jurnal Ilmiah Peternakan. 2015 3(2): 34-38.

4. Nozad S, Ramin AG, Moghadam G, et al. : Relationship between blood urea, protein, creatinine, triglycerides and macro-mineral concentrations with the quality and quantity of milk in dairy holstein cows. Vet Res For. 2012; 3(1):55 -59.

5. Lager K, Jordan E:The metabolic profile for the modern transition dairy cow. The Mid-South Ruminant Nutrition Conference. Texas Agrilife Extension Service, Texas. 2012.

6. Stojevic Z, Filipovic N, Bozic P, et al. : The metabolic profile of Simmental service bulls. Vet Arhiv. 2008; 78(2):123-129.

7. Frandson RD: Blood and other body fluids. 4ed. Gadjah Mada University Press. Yogyakarta. 1992.

8. Adam M., Lubis TM, Abdyad B, Number of erythrocytes and haematocrit value of aceh cattle and bali cattle in Lembahselawah subdistrict, Aceh Besar District. Jurnal Medika Veterinaria. 2015; 9(2): 115-118.

9. Wood D, Quiroz-Rocha GF: Normal Hematology of Cattle. In: Schalm's Veterinary Haematology. 6ed. Wiley, Ames, IA. 2010.

10. Dukes HH, Swenson, MJ: Dukes' Physiology of Domestic Animals. 10th Ed. Cornel University Press. Ithaca. 1984.

11. Wardhana AH, Kenanawati E, Nurmawati, et al.: The effect of "patikan kebo" (Euphorbia hirta L) 
preparations on erythrocyte number, haemoglobin level and haematocrit value of chicken infected with Eimeria tenella. JITV. 2001; 6(2): 234-239.

12. Ali A, Ismoyowati, Indrasanti D: Number of erythrocytes haemoglobin level and hematocrit various local ducks after administration of probiotic in ransum. Jurnal Ilmiah Peternakan. 2013; 1(3): 10011013.

13. Radostids OM, Gay CC, Hinchcliff KW, et al:: Veterinary Medicine: A textbook of the diseases of cattle, horses, sheep, pigs and goats. 10th ed. Saunders Elsevier. Spain. 2007.

14. Mitruka BM, Rawnsley HM: Clinical Biochemical and Hematological Reference Values in Normal Experimental Animals and Normal Humans. 2nd ed. Year Book Medical Publishers Inc., Chicago. 1981.

15. Kendran AAS, Damriyasa IM, Dharmawan NS, et al. : Blood clinical chemistry profiles of the bali cattle. Jurnal Veteriner. 2012; 13(4):410-415.

16. Mitruka BM, Rawnsley HM, Vadehra BV: Clinical Biochemical and Hematological Reference Values in Normal Experimental Animals. Masson Publishing, Inc., New York. 1977.

17. Harper HA, Rodwell VW, Mayers P: Review of Physiological Chemistry. 17th Edition. Lange Metical Publication, Los Altos, California. 1977.

18. Tahuk, PK, Dethan AA, Sio S: The Blood Glucose and Urea Profile of Male Bali Cattle on Greenlot Fattening at Smallholder Farms. J. Agripet. 2017; 7(2):105-112.

19. Tillman AD, Hartadi H. Reksohadiprojo S, et al.: Basic animal feed. 4ed. Gadjah Mada University Press, Yogyakarta. 1991.
20. Parakkasi A: Nutrition and feed for ruminant. Universitas Indonesia Press, Jakarta. 1999.

21. Wahyuni RS, Retno B, Romziah S:Blood Glucose and Total Blood Protein Profile in Sheep Provided With Lactic Acid Bacteria and Yeast on King Grass and Rice Straw. J. Ilmiah Kedokteran Hewan.2011; 4(1):65-70.

22. Cheng ZJ, Hardy RW: Protein and lipid sources affect cholesterol concentrations of juvenile Pacific white shrimp, Litopenaeus vannamei (Boone). J Animal Science.2004; 82(4):1136-1145.

23. Murray RK, Daryl KG, Peter AM, et al.: Harper's Biochemistry. EGC Medical book publisher. Jakarta. 2003.

24. Isa HA:. Comparison of blood cholesterol of Ongole cross and Simental-Ongole cross in Slemanand Kulon Progo and its relationship to service per conception, Thesis. Faculty of Veterinary Medicine. Gajah Mada University, Yogyajarta. 2014.

25. Prihatno SA, Kusumawati A, Karja NWK, et al:: Blood Biochemical Profile in Repeat Breeding Dairy Cows. $J$. Vet Med. 2013; 7(1):29-31.

26. Roseler DK, JD Ferguson, Sniffen CJ, et al.: Dietary protein degradability effect on milk urea nitrogen and non-protein nitrogen in Holstein cows. J. Diary Sci. 1993; 58(1):525-534

27. Van Saun RJ: Blood profiles as indicators of nutritional status. Adv dairy tech. 2000; 12; 401. 